\title{
Late Cretaceous crinoids (Echinodermata) from the southwestern margin of the Holy Cross Mts. (southern Poland) and phylogenetic relationships among bourgueticrinids
}

\author{
Rafał $\operatorname{Lach}^{1} \cdot$ Mariusz A. Salamon ${ }^{1}$
}

Received: 6 January 2015/Accepted: 20 May 2016/Published online: 17 June 2016

(c) The Author(s) 2016. This article is published with open access at Springerlink.com

\begin{abstract}
A systematic account of crinoids from the Upper Coniacian-Lower Campanian of the southwestern margin of the Holy Cross Mountains in southern Poland is presented. Seven crinoid taxa [Marsupites testudinarius (von Schlotheim), Bourgueticrinus ellipticus (Miller), Bourgueticrinus sp., I.? granosus Valette, Isocrinus? sp., Nielsenicrinus carinatus Roemer and Austinocrinus bicoronatus (von Hagenow)] are described and illustrated. The new material from Poland extends down the stratigraphic range of Austinocrinus bicoronatus to the Lower Campanian. Morphometric data support that Bourgueticrinus ellipicus and B.? suedicus are conspecific. Taphonomy and paleoecology of recorded crinoid assemblages are discussed. Phylogeny of Cretaceous bourgueticrinids is also revisited.
\end{abstract}

Keywords Crinoidea $\cdot$ Late Cretaceous $\cdot$ Holy Cross Mountains $\cdot$ Poland $\cdot$ Taxonomy $\cdot$ Phylogeny

Kurzfassung Es wird ein systematischer Überblick zu den oberkretazischen (Ober-Coniacium bis Unter-Campanium) Crinoiden vom SW-Rand des Heiligkreuzgebirges (Südpolen) vorgestellt. Insgesamt werden 7 Seelilientaxa, Marsupites testudinarius (von Schlotheim), B. ellipticus (Miller), Bourgueticrinus sp., I.? granosus Valette,

Electronic supplementary material The online version of this article (doi:10.1007/s12542-016-0313-9) contains supplementary material, which is available to authorized users.

Rafał Lach

rafal_lach86@o2.pl

1 Department of Palaeontology and Stratigraphy, Faculty of Earth Sciences, University of Silesia, Będzińska 60, 41-200 Sosnowiec, Poland
Isocrinus? sp., Nielsenicrinus carinatus Roemer und Austinocrinus bicoronatus (von Hagenow), beschrieben und abgebildet. Die neuen Funde aus Polen erweitern die stratigraphische Reichweite von Austinocrinus bicoronatus bis in das frühe Campanium. Desweiteren implizieren die vorliegenden morphometrischen Daten, dass Bourgueticrinus ellipicus und B.? suedicus konspezifisch sind. Taphonomie und Paläoökologie der Crinoiden-Vergesellschaftung werden diskutiert, wie auch die Phylogenie der kreidezeitlichen Bourgueticriniden revidiert wird.

Schlüsselwörter Crinoidea Oberkreide .

Heiligkreuzgebirge · Polen · Taxonomie $\cdot$ Phylogenie

\author{
Abbreviations \\ GIUS Laboratory of Palaeontology and Stratigraphy of \\ the University of Silesia \\ GPIH Geologisch-Paläontologisches Museum in \\ Hamburg \\ MB Museum für Naturkunde in Berlin \\ NHML Natural History Museum in London
}

\section{Introduction}

In recent years, major progress has been achieved through taxonomic studies on the Late Cretaceous crinoids from Poland (Salamon 2009; Salamon and Gorzelak 2010). Most recently, Lach (2016) completed and summarized our knowledge on this echinoderm class from this country. He also stressed that the Late Cretaceous crinoids are best known from the Vistula River Valley, Miechów Trough, Podlasie area, Upper Nysa Trough and Pomerania area (see also Niedźwiedzki and Salamon 2005; Salamon and Gorzelak 2010, 2011 and literature cited therein). A 
systematic account of Late Cretaceous crinoids from Opole, Roztocze, and the southwestern margin of the Holy Cross Mountains was also provided (see Appendix 1 in Lach 2016).

According to Remin (2004) and Lach (2016), the following crinoid taxa occur in the Upper Cretaceous sediments in the southwestern margin of the Holy Cross Mountains: Isocrinus? sp., Bourgueticrinus sp. (Coniacian); Bourgueticrinus sp., Comatulida indet., Marsupites testudinarius (von Schlotheim) (Santonian); Isocrinida indet. (Campanian). Thanks to the new findings of crinoid material from this region, we are able to provide herein a first detailed systematic description.

The material described in the present paper is housed at the Laboratory of Palaeontology and Stratigraphy of the University of Silesia (acronymed GIUS 9-3651).

\section{Geological framework}

The study area is located in the southwestern Mesozoic margin of the Holy Cross Mountains (HCM). This area is bordered by the so-called Szczecin-Łódź-Miechów Synclinorium to the south and the Mid-Polish Anticlinorium to the north. A number of outcrops of Upper Coniacian, Santonian, and Lower Campanian sediments are located near Kije and Lipnik villages. The so-called Lipnik-Kije depositional basin was a part of the Miechów Trough (Remin 2010; Fig. 1). Herein, a 150-m-thick, almost complete Santonian series is present (Remin 2010). However, according to Remin $(2004,2010)$, most of the outcrops are usually overgrown. A detailed description of the studied localities (Fig. 1) is given below (lithology and biostratigraphy from Remin 2004, 2010; Walaszczyk 1992).

Outcrop no. 1 (Fig. 1a). Seven small outcrops (marked from $A$ to $G$ in Fig. 1b) located along the railway line were re-excavated during field works in 2013. 1.5-2 m-thick marly limestones and marls (commonly embedded with opoka) correspond to the Late Santonian and Early Campanian age. Sediments from the first outcrop ("A") probably belong to the Late Santonian inoceramid Sphenoceramus patootensiformis Zone. The next outcrops ("B-D", and partly "E") represent the crinoid Marsupites testudinarius Zone. The outcrops referred to as "E"-"G" are probably Lower Campanian? in age as supported by the occurrence of ammonite Gaudyceras mite (details in Remin 2004, 2010).

Outcrop no. 2 (Fig. 1a). Outcrop with Upper Coniacian and Lower Santonian sediments is located in the northern part of Kije village. The Upper Coniacian grey thick-bedded opoka (=calcarenite) corresponds to the ammonite Texanites pseudotexanus Zone and inoceramid Sphenoceramus pachti Zone and ranges up to the Early Santonian ammonite Kitichnites emscheris/Nowakites savini Zone. The upper part of the section with Lower Santonian sediments (opoka) corresponds to the inceramid Cladoceramus undulatoplicatus Zone (Walaszczyk 1992). According to

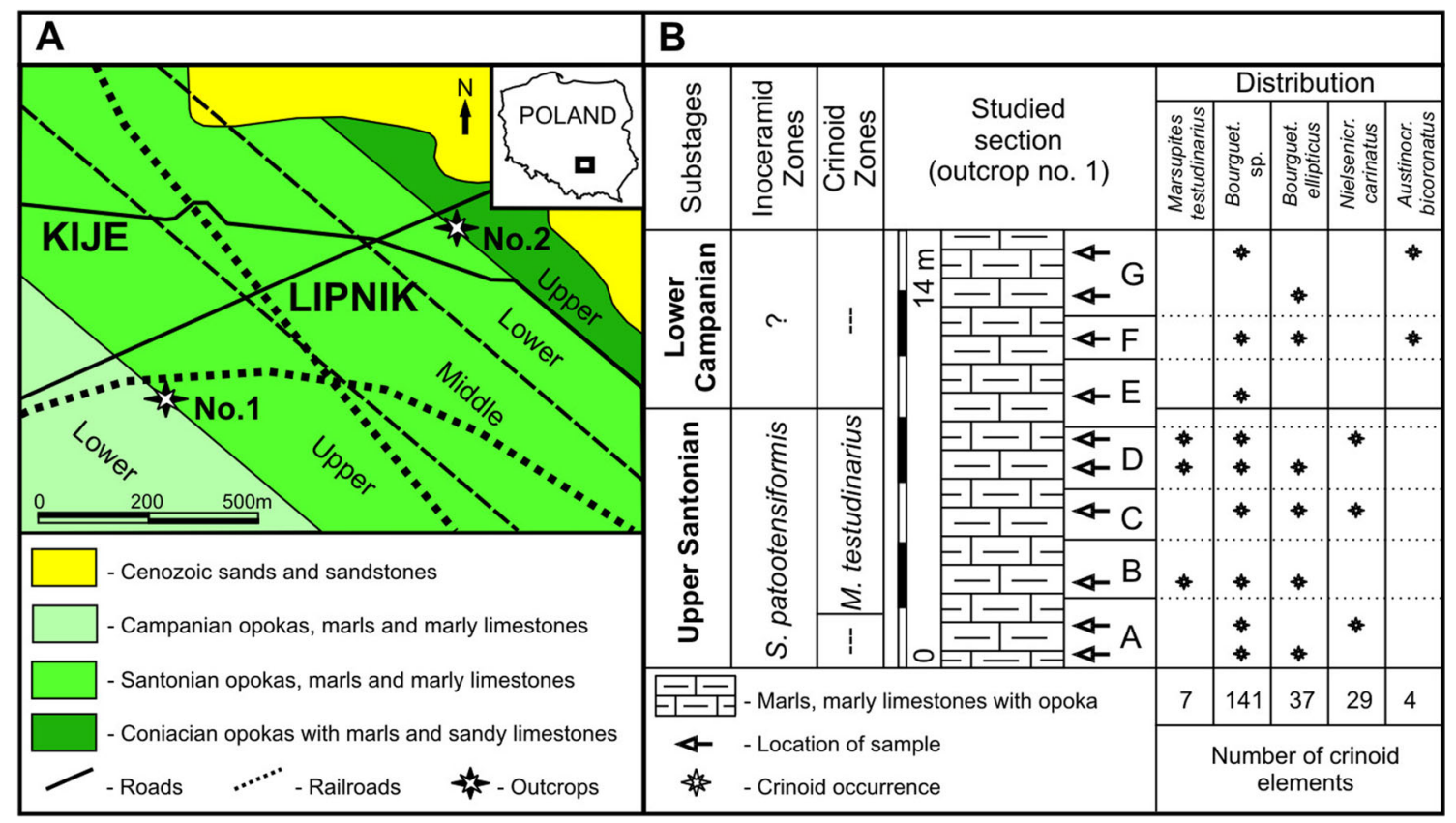

Fig. 1 a Map of Poland with enlarged studied localities (slightly modified from Remin 2004, 2010). b Section of the outcrop no. 1. and distribution of collected crinoid taxa (modified after Remin 2010; biostratigraphy after Walaszczyk 1992) 
Remin $(2004,2010)$, the total thickness of these sediments ranges from 20 to $25 \mathrm{~m}$. However, only a small $(\sim 1 \mathrm{~m})$ portion of this section is actually exposed. Herein, a small ( $\sim 0.5$-m-deep) pit was excavated. The occurrence of ammonite Texanites is indicative of a Coniacian age.

\section{Materials and methods}

During fieldwork (Spring and Autumn 2013), 10 rock samples of different ages (Santonian-Campanian), each weighing $10 \mathrm{~kg}$, were gathered (outcrop no. 1; for details see Fig. 1). Additionally, three bulk samples (each weighing $10 \mathrm{~kg}$ ) were taken from Coniacian sediments (outcrop no. 2). The samples were macerated with Glauber salt, washed with tap water, dried at $150{ }^{\circ} \mathrm{C}$, and sieved through decreasing mesh widths $(\varnothing 3.0,1.5,0.3 \mathrm{~mm})$ following the work of Salamon et al. (2007). The echinoderm ossicles were then picked up under a stereoscopic microscope. Some specimens were additionally cleaned mechanically or by means of perchlorate. Nearly 750 crinoid ossicles (thecae, thecal plates, columnals, pluricolumnals, brachial plates, and cirrals) were collected (Fig 2).

In the Coniacian samples, besides dozens of crinoid ossicles, several ophiuroid, echinoid, and asteroid ossicles were also found. In the Santonian samples, numerous crinoid elements were collected along with abundant echinoid, ophiuroid, and asteroid ossicles. The Campanian samples delivered numerous crinoids and only a few echinoid and asteroid ossicles. Apart from echinoderms, bryozoans, gastropods, and inoceramid bivalves were also found in the Coniacian-Campanian samples. A Coniacian sample yielded a single ammonite fragment.

Biometric measurements were made using a stereoscopic microscope SM800T and electronic digital caliper (accuracy $\pm 0.02 \mathrm{~mm}$ ). Statistical analyses were performed

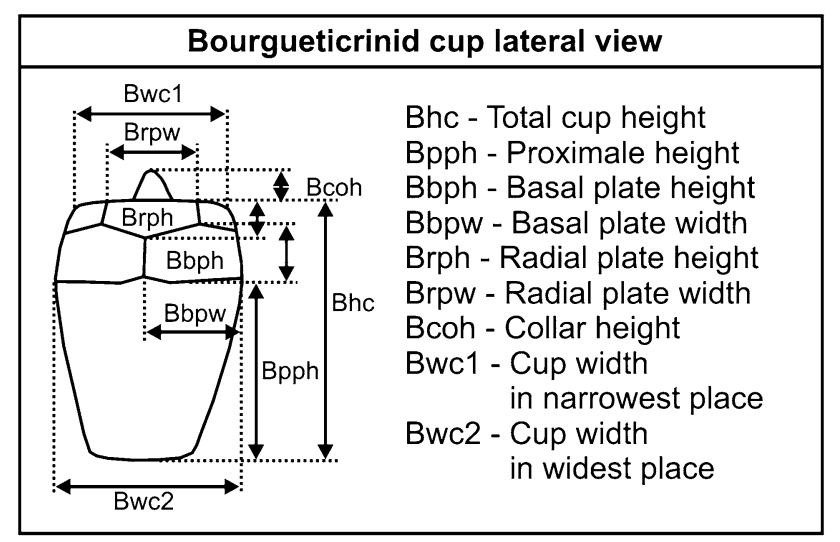

Fig. 2 Dimensions of bourgueticrinid cups used in the present study (idea after Głuchowski 1987, modified) using PAST software: PAlaeontological STatistics Version 1.94b (Hammer et al. 2001; for details see also Hammer and Harper 2006).

For comparison purposes, the Late Cretaceous crinoid collections (bourgueticrinids and marsupitids) housed at the Geologisch-Paläontologisches Museum in Hamburg (Gross Bülten and Lägerdorf collection, Hamburg, GPIH 4848-4850 and GPIH 40.1114/16-19, respectively), Museum für Naturkunde in Berlin (E.8411-8416), and at the Natural History Museum in London (Kent, Quidhampton and East Harnham near Salisbury collection, E45168-86 and E45320-6, respectively) were also examined.

\section{Systematic palaeontology}

Systematics used in this paper follows Hess and Messing (2011). We adopted Rasmussen's (1961) isocrinid classification and terminology.

Class Crinoidea Miller 1821

Subclass Articulata Miller 1821

Order Comatulida A.H. Clark 1908

Superfamily Uintacrinoidea Zittel 1879

Family Marsupitidae d'Orbigny, 1852

Genus Marsupites Mantell in Miller 1821

Type species Encrinites testudinarius von Schlotheim 1820

Diagnosis The theca is composed of 16 plates grouped in three circlets of large and convex radial, basal, and infrabasal plates.

Stratigraphic and geographic distribution Upper Cretaceous (Late Santonian) of Africa (Algeria, Madagascar), Asia (Gulf Coast, India, Kazakhstan, Turkmenistan), Australia (Australia), Europe (England, France, Germany, Poland, Ukraine), Northern America (Canada, USA).

Marsupites testudinarius (von Schlotheim 1820)

Figure $3 \mathrm{a}-\mathrm{j}$

* 1820 Encrinites testudinarius von Schlotheim: p. 339. 1961 Marsupites testudinarius (von Schlotheim)—Rasmussen: p. 396-400, pl. 59, Figs. 11-17.

1994 Marsupites testudinarius (von Schlotheim)—Milsom et al.: p. 596, text-Fig. 1a.

2004 Marsupites testudinarius (von Schlotheim)—Remin: p. 593.

v 2006 Marsupites testudinarius (von Schlotheim)Łukowiak and Gorzelak: p. 784-786, Fig. 2a.

v 2010 Marsupites testudinarius (von Schlotheim)—Salamon and Gorzelak: p. 15, Fig. 7d.

v 2011 Marsupites testudinarius (von Schlotheim)—Salamon and Gorzelak: p. 313, Fig. 2 i. 

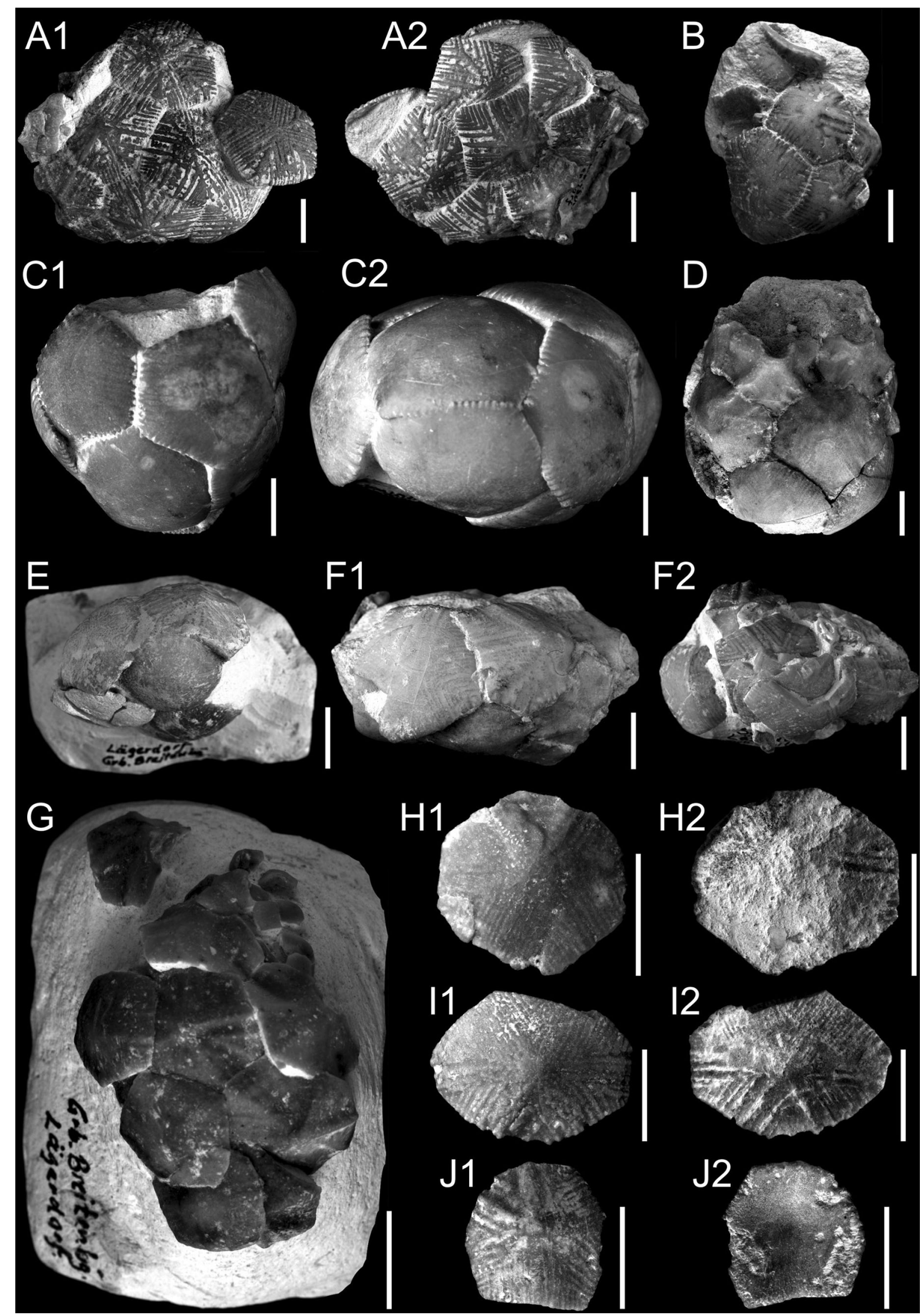

$\mathrm{J} 2 \mathrm{~A}$ S

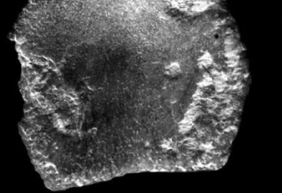


४Fig. 3 Santonian crinoid Marsupites testudinarius (von Schlotheim) from the southwestern margin of the Holy Cross Mountains and GPIH. Scale bars $1 \mathrm{~cm}$. a-g Thecae. Upper Santonian. Lägerdorf. GPIH 40.1114/16-19. h-j Thecal plates. Upper Santonian. LipnikKije Section. GIUS 9-3651/Mt/1-3

For a very detailed synonymy of Marsupites testudinarius see Lach (2016).

Studied material GIUS 9-3651/Mt: 7 thecal plates. GPIH 40.1114/16-19: 7 thecae, 15 brachials.

Diagnosis Theca is composed of three circlets of large and convex radial, basal, and infrabasal plates.

Description Thecal plates are of different sizes. They are mostly pentagonal or hexagonal in the case of basal plates. All plates are strongly convex. The plates with a maximum height of $21 \mathrm{~mm}$ are covered by 3-4 thick radiating ridges and between them numerous thin ridges are visible. Small plates with a minimum height of $13 \mathrm{~mm}$ are only covered by 3-4 thick radiating ridges. The inner surface of most plates is smooth. Only a few ossicles are covered by thin and long ridges on their inner surface. All thecal plates are thin $(1.60-1.80 \mathrm{~mm})$.

German specimens (GPIH): the thecae are of different sizes. Large specimens are spheroidal, ovoid, and strongly flattened. They consist of large plates with a maximum height of $22.5 \mathrm{~mm}$, which are strongly ornamented by radiating ridges. The precise shape of the small thecae is difficult to ascertain because of compaction. These thecae are composed of small and smooth plates with a maximum height of $12.5 \mathrm{~mm}$. The shape of $\mathrm{IBr}_{1}$ corresponds to the embayment in the radial plate. $\mathrm{IBr}_{2}$ are axilliaries. They are five-sided and possess upward-diverging sides. The articulation between $\mathrm{IBr}_{1}$ and $\mathrm{IBr}_{2}$ is syzygial. Few isolated brachial plates are secundibrachials; they are wedgeshaped and more or less angular; the plates are relatively low. Some of them are syzygial; others are muscular. The proximal, syzygial articulation is visible in a few specimens, and they have stout and radiating ridges. The pinnular sockets do not occur.

Remarks According to (Sieverts 1927; see also Brydone 1912 and Rasmussen 1961), two morphotypes of Marsupites can be distinguished. The lower part of the Marsupites zone is characterized by the presence of small and smooth thecae with only peripheral ornamentation of the plates (see also Łukowiak and Gorzelak 2006; Lach 2016). The upper part of the Marsupites zone is dominated by the presence of larger and strongly ornamented thecae. Rasmussen (1961) already mentioned that both morphotypes could co-occur. Furthermore, this latter synonymized many species of this genus and argued that the specimens described from the Campanian seem to be uncertain (see Rasmussen 1961, p. 400).

The material from Poland and Germany delivers both morphotypes. Though difficult to determine whether the thecal plates from Germany come from different stratigraphic intervals, we can only state with confidence that both morphotypes from Poland do not co-occur in the same layer, i.e., small and smooth plates were mostly found in the lower part of the section. Noteworthy is the fact that so far only large and strongly ornamented thecal plates have been recorded in Polish localities (details in Salamon and Gorzelak 2010, 2011; Lach 2016).

Stratigraphic and geographic distribution. Upper Cretaceous (Late Santonian) of Africa (Algeria, Madagascar), Asia (Gulf Coast, India, Kazakhstan, Turkmenistan), Australia (Australia), Europe (England, France, Germany, Poland, Ukraine), Northern America (Canada, USA).

Suborder Bourgueticrinina Sieverts-Doreck 1952 Family Bourgueticrinidae de Loriol 1882

Genus Bourgueticrinus d'Orbigny 1841

Type species Apiocrinites ellipticus Miller 1821

Diagnosis The theca with undivided proximale formed by one or several fused proximal columnals. Above the proximale occur a ring of basals and alternating with the basals a circle of radials.

Remarks. Bourgueticrinus elegans is the only bourgueticrinid that possesses no trace of basals.

Stratigraphic and geographic distribution Upper Cretaceous (Cenomanian)-Paleogene (Eocene) of Europe (Belgium, Denmark, England, France, Germany, Italy, Netherlands, Poland, Russia, Sweden, Ukraine), Northern America (USA).

Bourgueticrinus ellipticus (Miller 1821)

Figures 4a-f, 5a-f

* 1821 Apiocrinites ellipticus-Miller: p. 33, Figs. 1-7. 1841 Bourgueticrinus ellipticus Miller-Orbigny: p. 95, pl. 17, Figs. 1-6.

1848 Bourgueticrinus milleri-M'Coy: p. 405.

1850 Apiocrinus ellipticus Miller-Forbes in Dixon: p. 343, pl. 20, Figs. 12-16, 19, 25.

1881 Mesocrinus suedicus-Carpenter: p. 130, pl. 6, Figs. 3-7.

1917 Volvola elliptica (Miller)_Valette: p. 93, Fig. 3.

1961 Bourgueticrinus ellipticus (Miller)-Rasmussen: p. 182-184, pl. 24, Figs. 11-16, pl. 60, Fig. 2.

1961 Bourgueticrinus suedicus (Carpenter)-Rasmussen: p. 196-197, pl. 27, Fig. 1-8. 

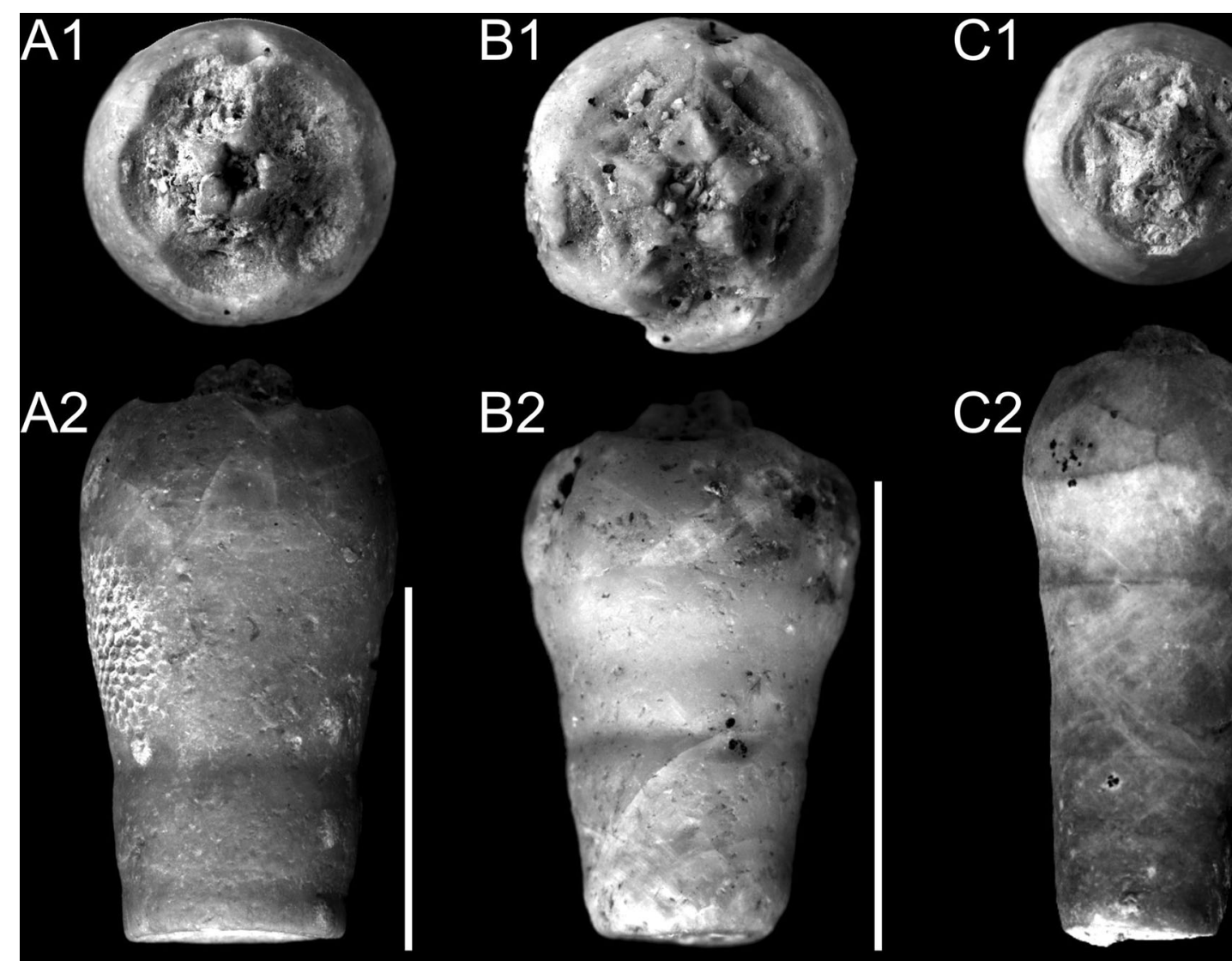

B2
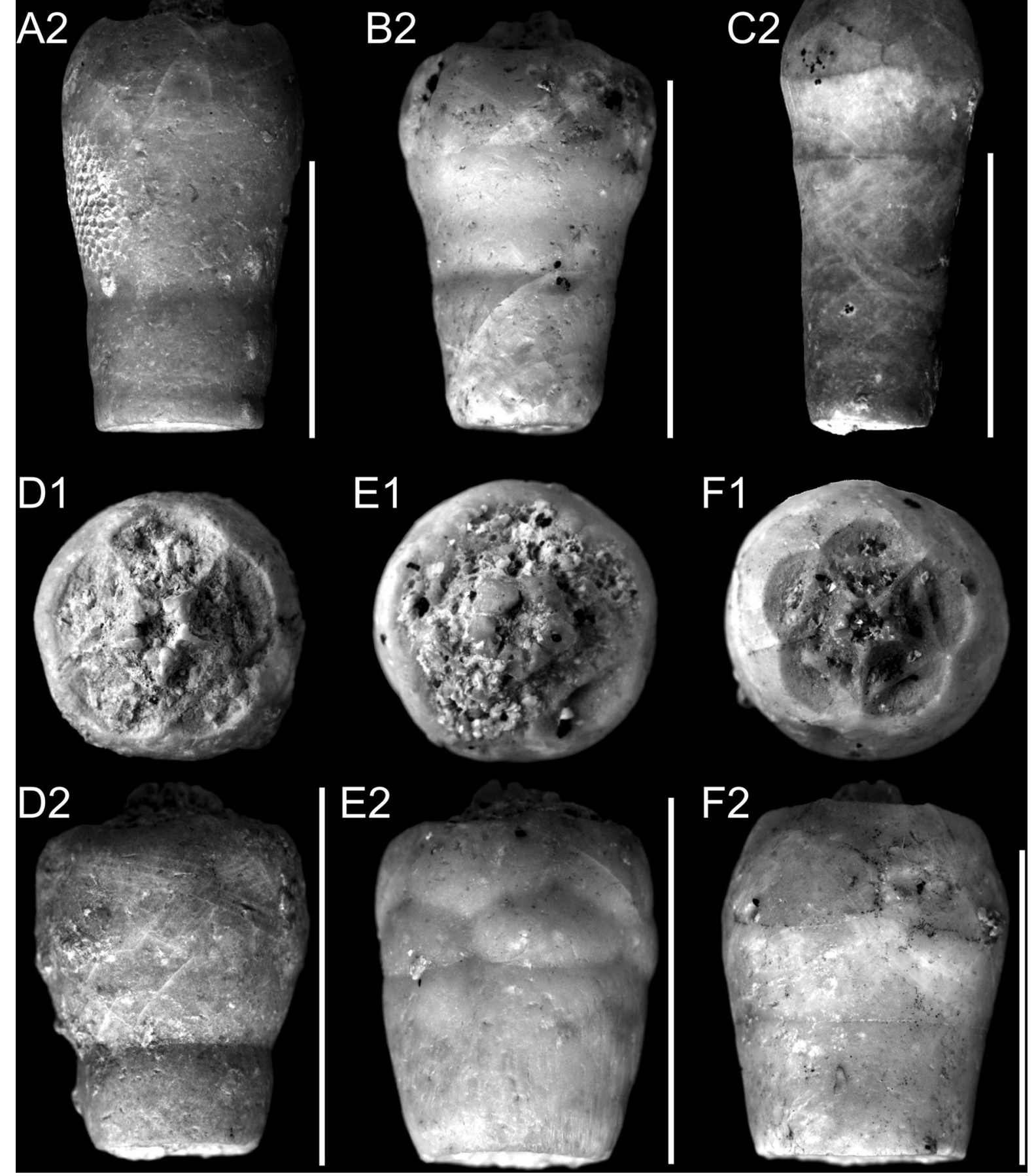
4Fig. 4 Upper Cretaceous crinoids from the southwestern margin of the Holy Cross Mountains. Upper Santonian/Lower Campanian. All from Lipnik-Kije Section. Scale bars $1 \mathrm{~cm}$. A-F. Bourgueticrinus ellipticus (Miller). A1, A2 Thecae. Specimen with high collar and sloping articular faces. Upper and lateral views, respectively. GIUS 9-3651/Be/1. B1, B2 Thecae. Specimen with high collar and sloping articular faces. Upper and lateral views, respectively. GIUS 9-3651/ $\mathrm{Be} / 2$. C1, C2 Thecae. Specimen with small collar and sloping articular faces. Upper and lateral views, respectively. GIUS 9-3651/ Be/3. D1, D2 Thecae. Specimen with high collar and sloping articular faces. Upper and lateral views, respectively. GIUS 9-3651/Be/4. E1, E2 Thecae. Specimen with high collar and sloping articular faces. Upper and lateral views, respectively. GIUS 9-3651/Be/5. F1, F2 Thecae. Specimen with small collar and sloping articular faces. Upper and lateral views, respectively. GIUS 9-3651/Be/6

\section{Bourgueticrinus ellipticus (Miller)—Klikushin:} p. 818 , Fig. 4d, e, f.

1995 Bourgueticrinus suedicus (Carpenter)—Jagt: p. 191, Figs. 5, 7.

1999 Bourgueticrinus? suedicus (Carpenter)—Jagt: p. 129-130, pl. 31, Figs. 2-3, 5, 9, 11, ? pl. 36, Figs. 5-6, ?pl. 38, Figs. 8-9.

v 2002 Bourgueticrinus ellipticus (Miller)—Smith and Wright: p.256, pl. 50, Fig. 6.

v 2010 Bourgueticrinus cf. ellipticus (Miller)—Salamon and Gorzelak: p. 11-12, pl. 5a.

v 2010 Bourgueticrinus? suedicus (Carpenter)-Salamon and Gorzelak: p. 14, pl. 4b.

v 2011 Bourgueticrinus? suedicus (Carpenter)—Salamon and Gorzelak: p. 316, Fig. 3g.

Studied material. GIUS 9-3651/Be: 37 thecae, some of them with proximale and/or proximal columnals. GPIH 4848-4850: 453 thecae and proximale. MB E.8411-8416: 37 thecae. NHML E45168-86, E45320-6: 100 thecae.

Dimensions See supplementary materials.

Diagnosis (emended) Thecae are claviform, pyriform, conical, or pear-shaped. The diameter reaches its maximum at the top of the proximale or at the basals. The suture lines are distinct. The facets are horizontal or sloping outwards. The base of the proximale is elliptical or circular. The collar may be high, strongly reduced, or absent.

Description The thecae are smooth, large, claviform to pyriform, sometimes conical and pear-shaped. The basals and radials are five-sided and contact each other; they are usually of similar size; however, in some specimens they can be slightly higher than the others (see supplementary materials). The suture lines between proximale, basals, and radials are distinct; in some cases the suture lines are slightly depressed. The facets are lobate. The dorsal ligament fossae are concave and possess a shallow pit. The facets are horizontal, or slope more or less outwards and can form a high collar around the radial cavity; some collars are lower (1/4-1/2 of the height of the highest collars). The lateral ridges are relatively low and inconspicuous. The dorsal ligament fossae can be large and interarticular ligament fossae are distinctly smaller and separated by oblique ridges. The proximale, which constitutes the large part of the theca, is elliptical or circular in outline at the base. The largest theca diameter is observed at the top of the proximale or at the basals. The radial cavity is small or medium-sized. The columnals are subcylindrical with small and rounded lumen, and with synarthrial facets.

Remarks. Rasmussen (1961) noticed that B. ellipticus was very similar to B.? suedicus and B. hureae (Valette). He also has mentioned that the first two species were restricted to different stratigraphic levels, which strengthens their taxonomic separation. However, the stratigraphic ranges of both species seem to overlap, as recently suggested by several authors. Furthermore, morphometric data suggest that B.? suedicus and B. ellipticus are conspecific. More details can be found in the Morphological variation of Bourgueticrinus section.

Stratigraphic and geographic distribution: Upper Cretaceous (Lower Turonian-Upper Campanian) of Europe (Belgium, Czech Republic, England, France, Germany, Sweden, Poland, Russia, Ukraine), and Asia (Russia and its former Asian republics).

\section{Bourgueticrinus sp.}

Figure 6a-c

Studied material. GIUS 9-3651/B: 178 columnals, seven deformed thecae.

Description The columnals are of different sizes and shapes. Most of them are medium-sized, cylindrical, barrelshaped, with elliptical ends that constricted medially. The facets are smooth or possess rhizocrinid pattern and fulcral ridge. The lateral surfaces are mainly smooth, planar, convex, or concave. The thecae are small, deformed, elongated, and thin. The sutures in a few cases are easily visible. The radial cavities are small and rounded.

Remarks Isolated bourgueticrinid columnals, which are strongly differentiated in shape and size, cannot be classified to the species-level. Similarly, the thecae at hand are small (juvenile?) and strongly deformed, which hinders their precise taxonomic affiliation (for comparison see Jagt and Salamon 2007; Salamon and Gorzelak 2010, 2011).

Stratigraphic and geographic distribution. Upper Cretaceous (Cenomanian)-Paleogene (Eocene) of Europe (Belgium, Denmark, England, France, Germany, Italy, Netherlands, Poland, Russia, Sweden, Ukraine), Northern America (USA). 

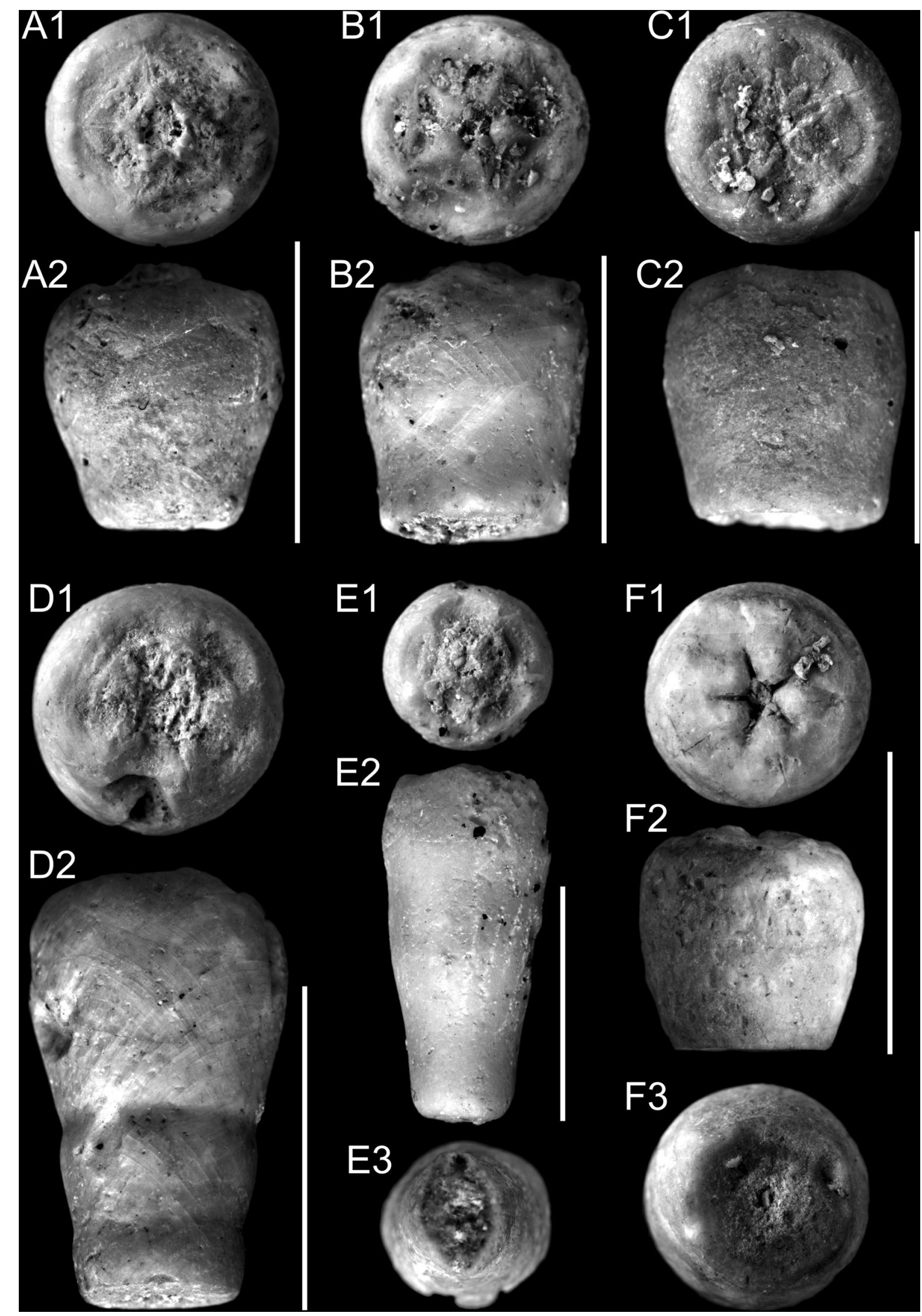
4Fig. 5 Upper Cretaceous crinoids from the southwestern margin of the Holy Cross Mountains. Upper Santonian/Lower Campanian. All from Lipnik-Kije Section. Scale bars $1 \mathrm{~cm}$. a-f. Bourgueticrinus ellipticus (Miller). A1, A2 Thecae. Specimen with small collar and sloping articular faces. Upper and lateral views, respectively. GIUS 9-3651/Be/7. B1, B2 Thecae. Specimen with small collar and horizontal articular faces. Upper and lateral views, respectively. GIUS 9-3651/Be/8. C1, C2 Thecae. Specimen without collar and horizontal articular faces. Upper and lateral views, respectively. GIUS 9-3651/Be/9. D1, D2 Thecae. Specimen without collar and sloping articular faces. Upper and lateral views, respectively. GIUS 9-3651/ Be/10. E1-E3 Thecae. Specimen with small collar, sloping articular faces, and elliptical cup base. Upper, lateral, and lower views, respectively. GIUS 9-3651/Be/11. F1-F3 Thecae. Specimen without collar, sloping articular faces, and circular cup base. Upper, lateral, and lower views, respectively. GIUS 9-3651/Be/12

Order Isocrinida Sieverts-Doreck 1952

Suborder Isocrinina Sieverts-Doreck 1952

Family Isocrinidae Gislén 1924

Subfamily Isocrininae Gislén 1924

Genus Isocrinus von Meyer in Agassiz 1836

Type species. Isocrinites pendulus von Meyer 1836

Diagnosis The species presents with a cup with small basals that are visible only from outside and not forming contiguous circlet. Identified as isocrinids with columnals that possess an elliptical petal floor surrounded by thin crenullae.

Stratigraphic and geographic distribution Triassic (?Carnian), Lower Jurassic - recent of the whole world.

\section{Isocrinus? granosus Valette 1917}

Figure $6 \mathrm{e}-\mathrm{g}$

? 1850 Pentacrinus sp.—Dixon: p. 343, pl. 19, Fig. 2, pl. 20, Figs. 6, 7.

1961 Isocrinus? granosus Valette-Rasmussen: p. 130133, pl. 16, Figs. 6-12, pl. 60, Fig. 1.

1992 Isocrinus? granosus Valette-Klikushin: p. 131.

v 2010 Isocrinus? granosus Valette-Salamon and Gorzelak: p. 9, pl. 2A-D.

For very detailed synonymy of Isocrinus? granosus see Lach (2016).

Studied material GIUS 9-3651/Ig: 36 columnals (only internodal forms), 13 brachial plates, 45 cirrals?.

Diagnosis An isocrinid with articular face covered by granules or irregularities surrounding the lumen.

Description The columnals are (sub-)pentagonal to stellate in outline. The facet is covered by max. 18 long, thick, and rather short crenulae. The crenulae form granules or small irregularities around the lumen. The petal floors of moderate size are ellipsoidal in shape. The latera is covered by irregular tubercles located around the elevated, sharp keel.
The lumen is circular and small. Brachial plates are rather small, V-shaped, and cryptosyzygial. The cirrals are wide and short, or moderately long. They are elliptical or rounded in section. The cirral facets are straight or slightly concave. The lumen is moderately large and raised above the perilumen. The cirral latera is smooth.

Remarks. Isocrinid columnals with granulated latera are commonly ascribed to Isocrinus? granosus. Rasmussen (1961) illustrated I.? granosus with petals possessing 20 crenulae. Similarly ornamented isocrinid species $I$.? cenomanensis (Orbigny) possesses slightly larger number of crenulae. Furthermore, the petals of the latter species are strongly elongated (compare to those in Valette 1917, Fig. 18; Rasmussen 1961, pl. 17, Figs. 4-8). Finally, this species is only known from the Albian and Cenomanian of western Europe. The cirrals at hand were also tentatively assigned to I.? granosus. According to Lach (2016; see also Salamon and Gorzelak 2010), cirrals possessing moderate or large lumen, rising above the perilumen, might belong to comatulids (Comatulida). However, comatulid centrodorsals were not found in the Coniacian sediments of investigated localities.

Stratigraphic and geographic distribution Cretaceous (Albian-Campanian) of Europe (Belgium, Czech Republic, Denmark, England, France, Germany, Netherlands, Poland, Sweden, Switzerland).

Isocrinus? sp.

Figure 6d

Studied material. GIUS 9-3651/I: 290 columnals (252 internodals and 38 nodals), 11 pluricolumnals (up to two columnals), 87 brachials.

Description The columnals are small (with max. diameter up to $3 \mathrm{~mm}$ ), pentagonal, pentalobate, or stellate in outline. The nodal columnals are larger than internodals. The facet is covered by max. 26 thin crenulae per petal in case of larger columnals. The facet of small specimens is covered by max. 18 stout crenulae per petal. The crenulae form granules around the lumen, especially in larger specimens. The marginal crenulae are rather thick and adradially fused V-like. The facets are covered by broad areolae of variable width. The petal floors are drop-like, sometimes ellipsoidal. The latera is smooth and straight. The cirrus scars of nodals are small and elliptical in outline with the articulum directed upwards. The aboral lip is sometimes present. The lumen is small and circular. The $\mathrm{IBr}_{1}$ are smooth and unornamented. The $\mathrm{IBr}_{2}$ is axillary. The articulation of $\mathrm{IBr}_{1-2}$ is syzygial.

Remarks. Fossil isocrinoids are mainly known from stalk fragments. Rasmussen (1961) proposed use of the provisional genus name 'Isocrinus?' for such isolated skeletal 


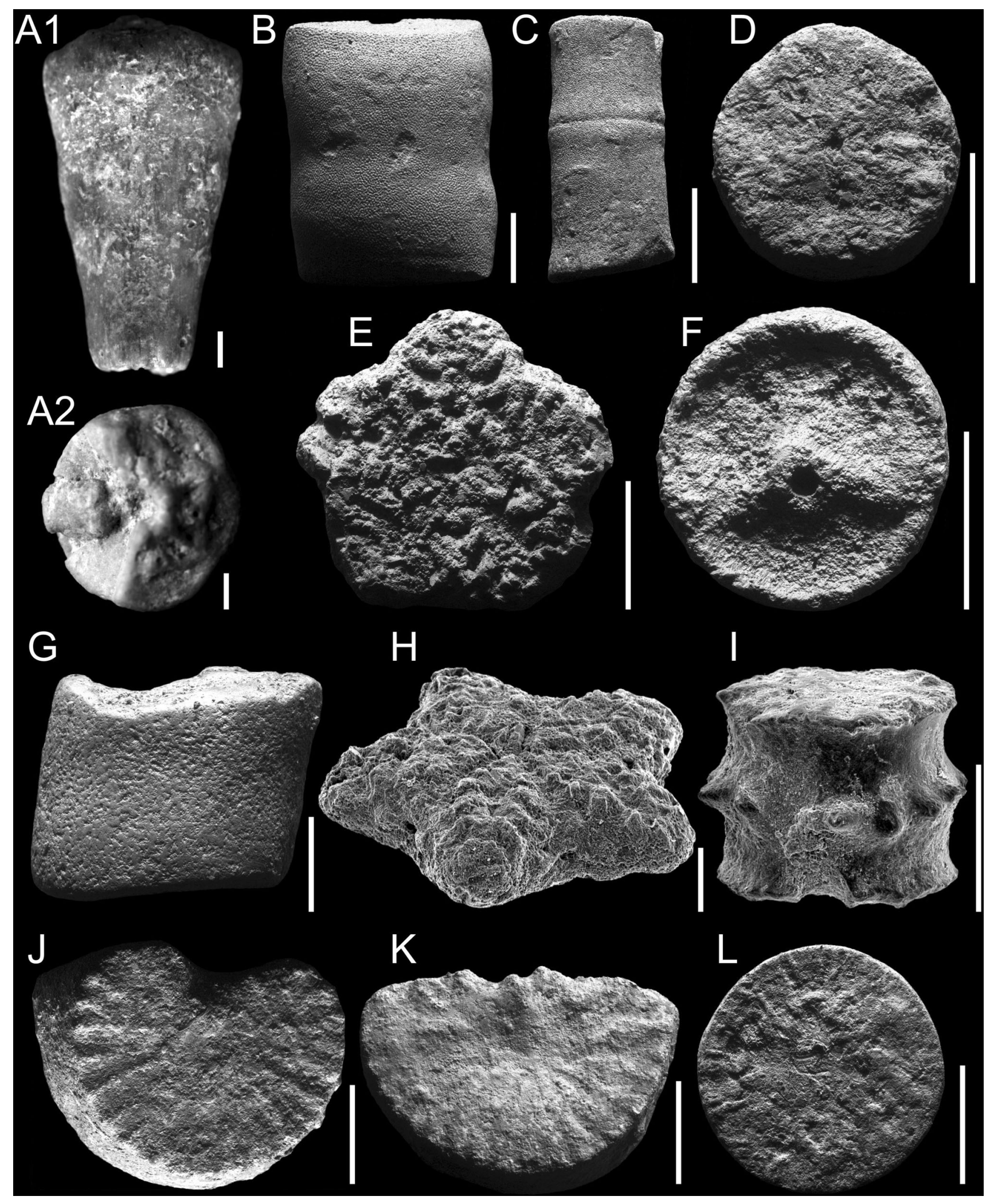


4Fig. 6 Late Cretaceous crinoids from the southwestern margin of the Holy Cross Mountains. All from Lipnik-Kije Section. Scale bars $1 \mathrm{~mm}$. A-C Bourgueticrinus sp. A1, A2 Thecae. Lateral and upper views, respectively. Lower Campanian. GIUS 9-3651/B/3. B-C Columnals. Lateral view. Upper Coniacian. GIUS 9-3651/B/10-11. D Isocrinus? sp. Columnals. Articular face. Upper Coniacian. GIUS 9-3651/I/3. E-G Isocrinus? granosus Valette. E. Columnals. Articular face. Upper Coniacian. GIUS 9-3651/Ig/3. F, G Cirrals. Lateral and upper views, respectively. Upper Coniacian. GIUS 9-3651/Ig/11-12. $\mathrm{H}-\mathrm{K}$ Nielsenicrinus carinatus Roemer. H-I. Columnals. Articular face and lateral views, respectively. Upper Santonian. GIUS 9-3651/ Nc/1-2. J, K Brachials. Upper view. Upper Santonian. GIUS 9-3651/ Nc/4-5. L Austinocrinus bicoronatus (von Hagenow). Columnals. Articular face. Lower Campanian. GIUS 9-3651/Ab/1

elements. Isolated isocrinid columnals with smooth latera were commonly described from the Upper Cretaceous of Poland as Isocrinus? sp. (e.g., Salamon and Gorzelak 2010, 2011, and literature cited therein). On the other hand, the columnals with ornamented latera were ascribed to Isocrinus? granosus Valette (Valette 1917; Rasmussen 1961; Salamon and Gorzelak 2010).

Stratigraphic and geographic distribution Triassic (?Carnian), Lower Jurassic-recent of the whole world.

Genus Nielsenicrinus Rasmussen 1961

Type species. Pentacrinus obsoletus Nielsen and Brünnich 1913.

Diagnosis. The isocrinid with radials and brachials that are coarsely granulate.

Remarks Nielsenicrinus is very similar to Cretaceous Iso-

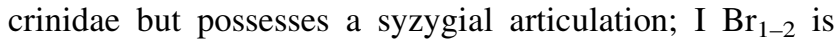
combined with a synarthial articulation $\mathrm{II}^{\mathrm{Br}_{1-2}}$.

Stratigraphic and geographic distribution. Lower Cretaceous (Hauterivian)-Paleogene (Oligocene) of Europe (Denmark, England, France, Germany, Netherlands, Sweden, Switzerland), Asia (Japan), and Australia (New Zealand).

\section{Nielsenicrinus carinatus (Roemer 1840)}

Figure $6 \mathrm{~h}-\mathrm{k}$

* 1840 Pentacrinites carinatus-Roemer: p. 26, pl. 6, Fig. 1.

1961 Isocrinus? carinatus (Roemer)-Rasmussen: p. 115, pl. 20, Figs. 3-8.

1961 Isocrinus? minutus (Valette)-Rasmussen: p. 141-143, pl. 15, Figs. 7-17.

1982 Pentacrinus? carinatus Roemer-Klikushin: p. 307. 1995 Nielsenicrinus carinatus (Roemer)—Jagt: p. 187, Figs. 3, 7.

1999 Nielsenicrinus carinatus (Roemer) -Jagt: p. 81-83; pl. 5, Figs. 4-7, 9-10, pl. 6, 7, 8 Figs. 1-9, ?10, 11; pl. 9-11; pl. 12, Figs. 1-6, 8. v 2011 Isocrinus? minutus (Valette)-Salamon and Gorzelak: p. 310-311, Fig. 2a.

For very detailed synonymy of Nielsenicrinus carinatus see Lach (2016).

Studied material GIUS 9-3651/Nc: 27 columnals (only internodals), two cryptosyzygial brachial plates.

Diagnosis Isocrinid with 'spiny' columnals and cryptosyzygial secundibrachials.

Description The columnals are circular to subpentagonal. The facets are covered by max. 16 crenulae. The marginal crenulae are clearly separated from the adradial crenulae. The adradial crenulae are sometimes reduced to granules. The lumen is small, circular. The latera is covered by granules or more commonly by small spines. The brachial plates, probably secundibrachials, are cryptosyzygial, relatively small, V- or U-shaped. The pinnular sockets are small, rounded, and deep.

Remarks The co-occurrence of cryptosyzygial brachials with 'spiny' isocrinid columnals suggests that these ossicles belong probably to Nielsenicrinus carinatus (Roemer). According to Oji et al. (1996), a diagnostic feature of nielsenicrinids is the presence of cryptosyzygies occurring between secundibrachials 3 and 4. Noteworthy is that (Salamon and Gorzelak 2010, but see also Jagt 1999) argued that Santonian 'spiny' species I.? minutus and Campanian $N$. carinatus are morphologically indistinguishable from each other.

Stratigraphic and geographic distribution Upper Cretaceous (Coniacian-Campanian) of Europe (Belgium, England, France, Germany, Netherlands, Poland, Russia, Ukraine), and Asia (Russia and its former Asian republics).

\section{Genus Austinocrinus de Loriol 1889}

Type species. Austinocrinus komaroffi de Loriol 1889 [=Pentacrinus erckerti Dames 1885].

Diagnosis Isocrinids with stout and very low circular and rounded columnals. The columnal facets possess a central ornament consisting of five interradial petals surrounded by very short and stout crenullae radiating from the petals. The crenullae are often replaced by adradial ridges. The marginal crenullae are often closely arranged or form isolated groups.

Stratigraphic and geographic distribution Upper Cretaceous (Early Campanian-Early Maastrichtian) of Africa (Tunisia), Asia (Caucasus, Turkmenistan), Europe (Belgium, Denmark, England, Germany, Netherlands, Poland, Spain, Sweden, Turkey), and South America (Mexico).

Austinocrinus bicoronatus (von Hagenow 1840)

Figure 61 
* 1840 Pentacrinus bicoronatus-Hagenow: p. 663, pl. 9, Fig. 12.

1846 Pentacrinus bicoronatus Hagenow-Boll: p. 209.

1892 Pentacrinus bicoronatus Hagenow-Stolley: p. 249, 253, pl. 10, Figs. 2-6.

1904 Pentacrinus bicoronatus Hagenow-Jaekel: p. 195, Fig. 11.

1913 Pentacrinus bicoronatus Hagenow-Nielsen: p. 81. 1938 Isocrinus (Pentacrinus) bicoronatus (Hagenow)Brydone: p. 4.

1961 Austinocrinus bicoronatus (Hagenow)-Rasmussen: p. 29-31, pl. 1, Figs. 1-9.

v 1987 Austinocrinus bicoronatus (Hagenow) —Wright and Smith: p. 202, pl. 44, Figs. 1-2.

1992 Austinocrinus bicoronatus (Hagenow)—Klikushin: p. $118,154,160,180$.

1995 Austinocrinus bicoronatus (Hagenow)—Jagt: p. 186, Figs. 3, 7.

1999 Austinocrinus bicoronatus (Hagenow)—Jagt: p. 70-72, pl. 1, Figs. 1-2.

v 2002 Austinocrinus bicoronatus (Hagenow) —Smith and Wright: p. 252, pl. 49, pl. 1, 2.

v 2010 Austinocrinus bicoronatus (Hagenow)—Salamon and Gorzelak: p. 13, pl. 2 g.

Studied material GIUS 9-3651/Ab: four columnals (only internodals).

Diagnosis Isocrinid with articular faces that possess smooth and narrow areolae surrounded by very short crenulae.

Description The columnals are rounded to weakly subpentagonal. The facet is covered by smooth, rather narrow and lanceolate areolae that are bordered by short, V-shaped crenulae. The crenulae near the lumen are arranged in a form of granulae. The latera is smooth and straight. The lumen is smooth and circular.

Remarks Among six species of the genus Austinocrinus illustrated by Rasmussen (1961; A. bicoronatus, A. cubensis Valette, A. erckerti (Dames), A. mexicanus (Springer), A. rothpletzi Stolley, A. solignaci Valette), all are exclusively known from the Upper Cretaceous and Danian sediments (see also Klikushin 1975, 1982, 1983, 1985, 1992; Whittlesea 1991; Jagt 1999; Reich and Frenzel 2002; Reich et al. 2004). The first occurrence of this genus is in the Upper Campanian (with the exception of A. rothpletzi). Additionally, A. cubensis, A. mexicanus, and A. solignaci were documented only in Africa and northern America. Jagt (1999) reminded us that $A$ rothpletzi appears to be typical for the Late Campanian, although some other authors reported this species from the Santonian (e.g., Klikushin 1983). The latter species differs from A. bicoronatus in having a specific petaloid structure. Furthermore, in contrast to
A. bicoronatus, the columnals of $A$. rothpletzi are commonly pentagonal and (sub-)stellate and the marginal crenelae are distinct, long, and thin (compare Stolley 1892, pl. 10, Figs. 7-14; Jaekel 1904, Figs. 1-10; Sieverts-Doreck 1952, pl. 17, Figs. 1-13, pl. 18, Figs. 1-7, 12, text-Figs. 1-6; Rasmussen 1961, pl. 2, Figs. 1-9). These features allowed the assignment of the material at hand to A. bicoronatus. Jagt (1999) pointed out that the transitional forms are typical of the Campanian/Maastrichtian boundary. It is likely that the present form is also transitional between older A. rothpletzi and younger A. bicoronatus. On the other hand, it cannot be excluded that the age of the sediments in HCM was incorrectly established [the datation is only supported by the single specimen of ammonite Gaudryceras mite (von Hauer) (Remin 2004)].

Klikushin $(1975,1992)$ updated the species list of the genus Austinocrinus by: (1) A albaticus Klikushin $=A$. komaroffi and A. komarovi (Coniacian-Santonian; Crimea), (2) A. turkmenicus Klikushin (Santonian-Campanian). Klikushin (1975) also erected a new species from Turkmenistan, but in his monograph from 1992 he suggested that this new species should be assigned to A. rothpletzi (see also Jagt 1999). Donovan et al. (1994) also recorded Austinocrinus n.sp. from the Aptian of Jamaica, but further on they assigned their material to millericrinid crinoid Apiocrinites sp (Donovan et al. 1996).

Stratigraphic and geographic distribution Upper Cretaceous (Early Campanian-Early Maastrichtian) of Europe (Belgium, Denmark, England, Germany, Netherlands, Poland, Sweden).

\section{Taphonomy}

Taphonomic analyses of the material at hand indicate a state of preservation similar to those of other crinoid assemblages described so far from elsewhere in Poland (Jagt and Salamon 2007; Salamon et al. 2007, 2009; Salamon and Gorzelak 2010, 2011; Lach 2016). The majority of the crinoids are represented by isolated ossicles, although articulated cups and pluricolumnals are also present. The observed pattern of disarticulation and low frequency of abrasion or secondary alteration of ossicle shape (cf. Gorzelak and Salamon 2013; Salamon et al. 2014) suggest that after the death of these crinoids, their skeletons were not transported over considerable distance but probably stayed for a longer time at the sediment-water interface before final burial. Dissolution traces, evidence of mineral coating, and bioerosion are rarely observed in the ossicles at hand. Epibionts were observed on $21 \%$ of ossicles. They are represented by bryozoans assignable to Cyclostomata ("Berenicea" and Stomatopora), 
Cheilostomata (Calloporidae), as well as formaninifers (Bullopora?). Deformations of stereom (so-called swellings) were not observed, suggesting a post-mortem incrustation. Furthermore, $19 \%$ of ossicles bear various scratches and pits on the latera. They are mostly thin and slightly elongated (up to about a few $\mathrm{mm}$ ). Such traces were commonly interpreted as bite marks produced by predatory sea urchins (Gorzelak and Salamon 2009; Salamon and Gorzelak 2010; Baumiller et al. 2010; Gorzelak et al. 2012). It is noteworthy that Salamon and Gorzelak (2010) recorded a similar frequency $(24 \%)$ of bite marks in the Late Cretaceous crinoids from the Middle Vistula River Valley.

\section{Paleoecology}

Recorded crinoid assemblages are dominated by benthic forms. Bourgueticrinid crinoids were sessile forms permanently attached to the seafloor by radicular cirri. On the other hand, isocrinoids are considered as motile benthic forms capable of movement on the seafloor with arms (Baumiller and Messing 2007). The only stalkless crinoid recorded in the Upper Cretaceous of the Holy Cross Mountains is the comatulid species Marsupites testudinarius. The mode of life of these crinoids has been the source of considerable controversy. According to Hess and Messing (2011), Marsupites Mantell in Miller and Uintacrinus Grinnel are very similar to each other, and both are gathered into the superfamily Uintacrinoidea. Thecae of these crinoids are bowl-shaped, composed of thin plates displaying extremely long arms (e.g., Hess 1999). Representatives of the genus Marsupites are mostly known from the Santonian (e.g., von Schlotheim 1820; Miller 1821; Springer 1911; Sieverts 1927). Sieverts (1927) and Rasmussen (1961) stated that the different species of Marsupites are indeed a single species, M. testudinarius. Apart from Santonian occurrences, these crinoids were also recorded in the Campanian of Madagascar (Besairie 1936). This latter author documented very large specimens, which are now stored in the British Museum. However, Rasmussen (1961) mentioned that "this isolated, late stratigraphical occurrence of a Marsupites seems uncertain and may be incorrect". Representatives of the genus Uintacrinus (three species) are exclusively known from the Santonian. Although U. socialis Grinnel was based on complete specimens, $U$. anglicus (Brydone) is only known from isolated material. Rasmussen (1961) mentioned that the latter species differs from $U$. socialis by having the wrinkled surface of the radials and proximal brachials. The third species $U$. westfalicus Schlüter was synonymized by Rasmussen (1961) with U. socialis. Although Schlüter (1878) specified many morphological differences between both species, Springer (1901) argued that they are difficult to verify.

As mentioned above, much attention has been paid to the uintacrinid mode of life. The first interesting hypothesis was provided by Bather (1889). According to the latter author these crinoids were swimming forms possessing five arms raised upward and five others directed downward. Springer (1901) mentioned that these crinoids were not capable of swimming but rather lived in groups on the soft sea bottom. Somewhat later, Kirk (1911) suggested that they might be gregarious species that were swimming in some sort of a shoal towards the shallow sea for spawning purposes. Jaekel (1918) did not agree with the "swimming" hypothesis and argued that their skeletons were probably too massive. This latter source stated that these crinoids rested on the seafloor with broadly expanded arms. Abel (1927) assumed that $U$. socialis displayed a planktonic mode of life. Hyman (1955) hypothesized that these forms were able to swim with matted arms directed downward. Struve (1957) provided an interesting hypothesis suggesting that Unitacrinus displayed a mode of life akin to that of ophiuroids and asteroids. This latter suggested that the mouth of these animals was directed toward the bottom and that they were crawling like ophiuroids. In accordance with Hyman's (1955) hypothesis, Breimer and Lane (1978) argued that uintacrinids were planktonic forms with arms directed toward the bottom. These latter suggested that the thin thecae of these animals were filled with gas or oil. More recently, Milsom et al. (1994) postulated that these crinoids were benthic forms whose thecae were embedded in the sediment. The proximal part of their arms might have lain on the seafloor whereas the more distal portions might have been positioned upright, building a feeding bowl. In accordance, Hess (1999) argued that uintacrinids were benthic forms and their widespread paleogeographic distribution might reflect a planktonic juvenile stage of unusual duration among crinoids. Based on the functional morphology of arms and thecae, Seilacher and Hauff (2004) suggested that Uintacrinus was a hemipelagic dredger. These latter shared the previous hypothesis from Breimer and Lane (1978) that the thecae of these crinoids were filled with gas. Additionally, they argued that the distal portions of the arms were directed downward and were trailing on the seafloor, so that these animals could have been genuine deposit feeders. Seilacher and Hauff (2004) stressed that the taphonomic data were not in conflict with their idea. During storms, their arms likely tangled with each other, causing a buoyancy decrease and their fall to the seafloor. However, in our view the hemipelagic dredger hypothesis seems to be highly unlikely, as the filtration fans of these crinoids might have been particularly prone to clogging with sediment 
particles. Thus, the benthic lifestyle postulated by Milsom et al. (1994) and Hess (1999) is the most probable.

\section{Morphological variation of Bourgueticrinus ellipticus}

As mentioned above, the cups of B.? suedicus are morphologically similar to those of B. ellipticus. According to Rasmussen (1961), B.? suedicus and B. ellipticus display different stratigraphic ranges that justify their taxonomic separation. On the other hand, Rasmussen, when describing B. ellipticus and B.? suedicus, mentioned that these species are restricted to Turonian?, Coniacian?Campanian, and Santonian-Campanian, respectively. The scheme (Rasmussen 1961, p. 412) indicates that these two species may co-occur (review in Table 1 in Jagt and Salamon 2007). With respect to the morphological differences between B. ellipticus and B.? suedicus, it has been argued that: (1) B.? suedicus displays high collar on the theca, which is not observed in B. ellipticus; (2) in contrast to B.? suedicus, B. ellipticus displays almost horizontal facets; (3) the bases of the cups in B.? suedicus and B. ellipticus are elliptical and circular, respectively (compiled after Valette 1917; Rasmussen 1961; Klikushin 1982; Salamon and Gorzelak 2010). Rasmussen (1961) highlighted that the major diagnostic feature distinguishing both species is the presence of almost horizontal articular facets in B. ellipticus, whereas they are sloping in B.? suedicus.

In the present paper, a large collection of cups attributed to B.? suedicus and B. ellipticus from the Santonian of Germany (GPIH and MB), England (NHML), and Poland (Holy Cross Mountains) was investigated. It appeared that both species display a wide range of morphological variation. In particular, the inclination of the radial articular facet varies significantly, i.e., there are a number of 'transitional' forms. Furthermore, the height of the collar as well as the shape of the cup base vary significantly in these specimens (see Supplementary Appendix 1). For example, among 300 bourgueticrinid cups investigated from the Santonian collection of Hamburg, 107 specimens possess horizontal articular facets, among which $34.6 \%$ display an elliptical cup base. Furthermore, $52.3 \%$ of the specimens with horizontal articular facets yield a collar. The number of 'transitional' forms possessing slightly sloping articular facets is also large (96 specimens). Among these 'transitional' forms, the frequency of specimens displaying circular $(44.8 \%)$ and elliptical $(55.2 \%)$ cup bases is comparable. Also, the frequency of specimens with and without a collar does not differ significantly (75 and $25 \%$, respectively). The number of specimens with strongly sloping articular facets (97 specimens) is comparable to that of 'transitional' specimens as well as to those with horizontal articular facets. Among the forms with strongly sloping articular facets, the frequency of specimens with a circular cup base is high (34\%). Similarly, the frequency of specimens without a collar is significant $(25.8 \%)$.

To further test the reliability of separation between these two species, detailed biometric analyses were conducted. For this purpose, the collection from the Geologisch-Paläontologisches Museum in Hamburg appeared the most suitable since it is rich in well-preserved bourgueticrinid cups. Various morphological characters were measured (details in Supplementary Appendix 1). Biometric data of their cups revealed that they are not clustered into two morphologically distinct groups. For example, the height of the collar correlates positively with the total height of the cup (Spearman's rank-order correlation coefficient $P=0.25022, p=1.16 \mathrm{E}-05$; Fig. 7) and with the cup width (both in the narrowest (Spearman's rank-order correlation coefficient $P=0.21836$, $p=0.000138$; Fig. 8) and in the widest point (Spearman's rank-order correlation coefficient $P=0.16179$, $p=0.004969$; Fig. 9). Furthermore, after splitting these biometric data into two groups according to diagnosis (i.e., the first group comprising the forms with strongly sloping articular faces and the second one with slightly sloping or with horizontal articular faces), it appeared that they cannot be statistically segregated from each other. The non-parametric Mann-Whitney tests report a probability of $p \gg 0.05$ for equality of medians of the total cup height and width, proximale height, basal height and width, radial height and width, giving off non-significant differences in any case also after Bonferroni corrections. These data strongly support that B.? suedicus appears to comprise variants or ecophenotypes of a coeval, single species, B. ellipticus.

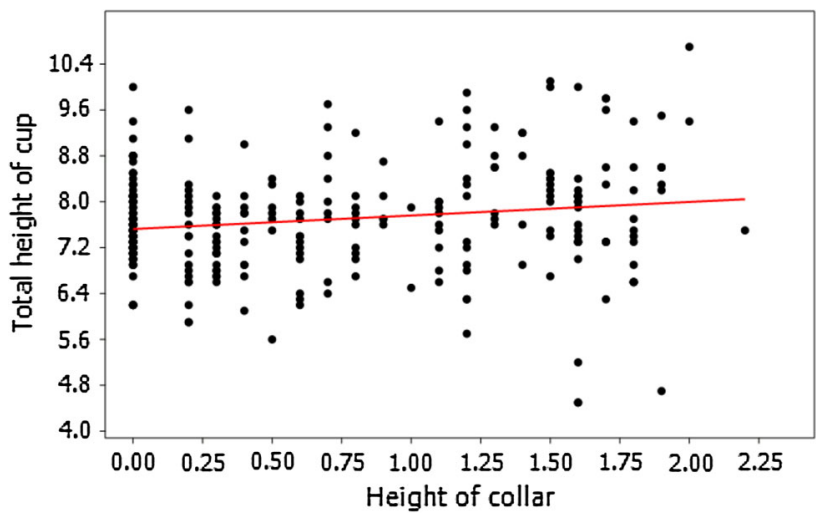

Fig. 7 Relationship between the height of the collar and the total height of the cup (specimens from Geologisch-Paläontologisches Museum in Hamburg) showing strong positive correlation (Spearman's rank-order correlation coefficient $P=0.25022, p=1.16 \mathrm{E}-05$ ) 


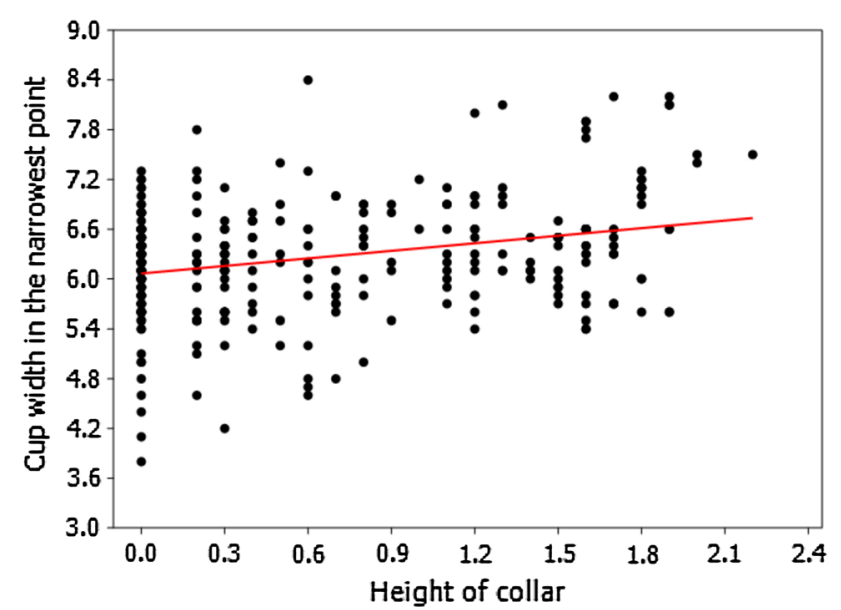

Fig. 8 Relationship between the height of the collar and the cup width in the narrowest point (specimens from Geologisch-Paläontologisches Museum in Hamburg) showing strong positive correlation (Spearman's rank-order correlation coefficient $P=0.21836$, $p=0.000138)$

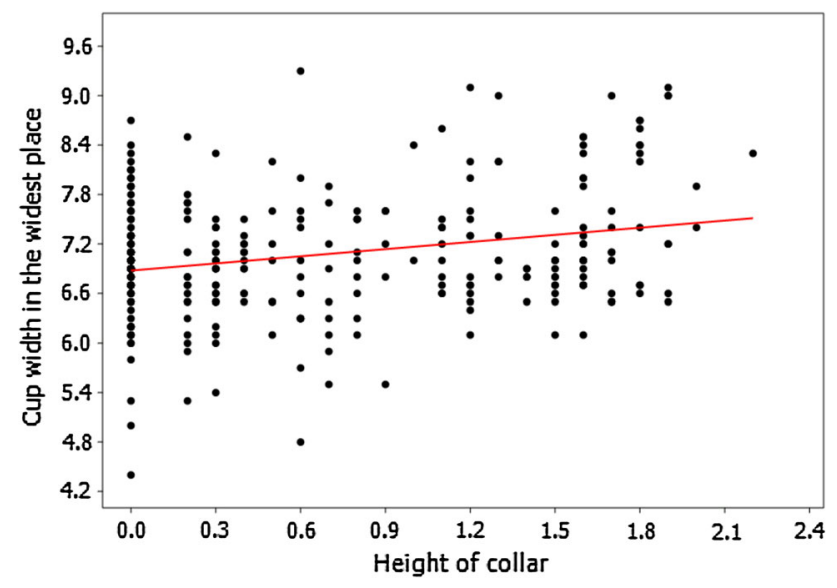

Fig. 9 Relationship between the height of the collar and the cup width in the widest point (specimens from Geologisch-Paläontologisches Museum in Hamburg) showing strong positive correlation (Spearman's rank-order correlation coefficient $P=0.16179$, $p=0.004969)$

\section{Phylogeny of Cretaceous bourgueticrinid species}

Phylogenetic relationships among Cretaceous bourgueticrinid species are controversial because of homoplasy in morphological characters (reversions and parallel evolution, e.g. Kjaer and Thomsen 1999). The simplicity of the morphology of these crinoids is commonly secondary in origin and is not inherited from their true ancestors. Indeed, recent molecular data support that homoplasies are very common in crinoids as a whole, which significantly limit the use of cladistic methods in phylogenetic analyses (Roux et al. 2013). Therefore, in the present paper, preliminary chronostratigraphic analysis was performed to explore possible relationships among Cretaceous bourgueticrinids (Fig. 10).

Bourgueticrinids, classified within the free-living comatulids (Comatulida), are a perfect example of neotenous forms because the adults retained the traits previously seen only in the larval stage (such as the stalk) (Hess and Messing 2011). The Late Cretaceous bourgueticrinid species are thought to be derived from the Early Cretaceous thiolliericrinids (Thiolliericrinidae), which are considered transitional forms between stalkless comatulids and stalked bourgueticrinids because they retained the column distal to the centrodorsal (e.g. Klikushin 1987). In some Early Cretaceous forms, such as Conoideocrinus, the disappearance of cirri on the centrodorsal is observed (Klikushin 1987). Thus, these crinoids might be ancestral to the Late Cretacous bourgueticrinids.

In the Cenomanian, divergence of the two main bourgueticrinid lineages occurred (Fig. 10). Bourgueticrinus brydonei Rasmussen known since the Cenomanian is among the oldest bourgeticrinids (Salamon 2007; Salamon and Gorzelak 2010). This species possesses a pear-shaped theca, widening out towards the basis. This form appears ancestral to two evolutionary lineages, i.e. the $B$. constrictus line, which includes forms with slender proximale and theca, and the B. ellipticus line, which includes forms with proximale widening out above and radial ring narrowing upwards. Various morphological forms evolved within the first line, i.e., species with stick-shaped thecae (B. baculatus), species with elongated proximale ( $B$. tenuis), species with reduced proximale and enlarged basals (B. bruennichinielseni) and species with reduced radials (B. danicus, $B$. hagenowii). Several evolutionary offspring represented by forms with wide, barrel-shaped proximale (B. cylindricus, B. maximus, B. elegans, B. utriculatus and $B$. granulosus) also originated from the second line. Among the species with barrel-shaped proximale, the only form displaying tubercular ornamentation on the latera is B. granulosus. B. cylindricus, in turn, developed depressions in the proximale and a theca with reduced radials. This species appears ancestral to B. papilliformis, which is characterized by further reduction of radials and enlarged basals, building a fusiform to claviform theca. $B$. maximus and B. globularis with reduced basals and barrelshaped or spherical theca, respectively, appear to be also closely related to B. cylindricus. From the evolutionary line represented by B. ellipticus, two additional species likely derived, i.e., B. utriculatus with pear-shaped theca displaying large and high basals, and B. elegans with completely reduced basals. $B$. pockrandti with enlarged basals and $B$. fritillus with elongated pear-shaped proximale are very closely related and probably descend from $B$. utriculatus. 


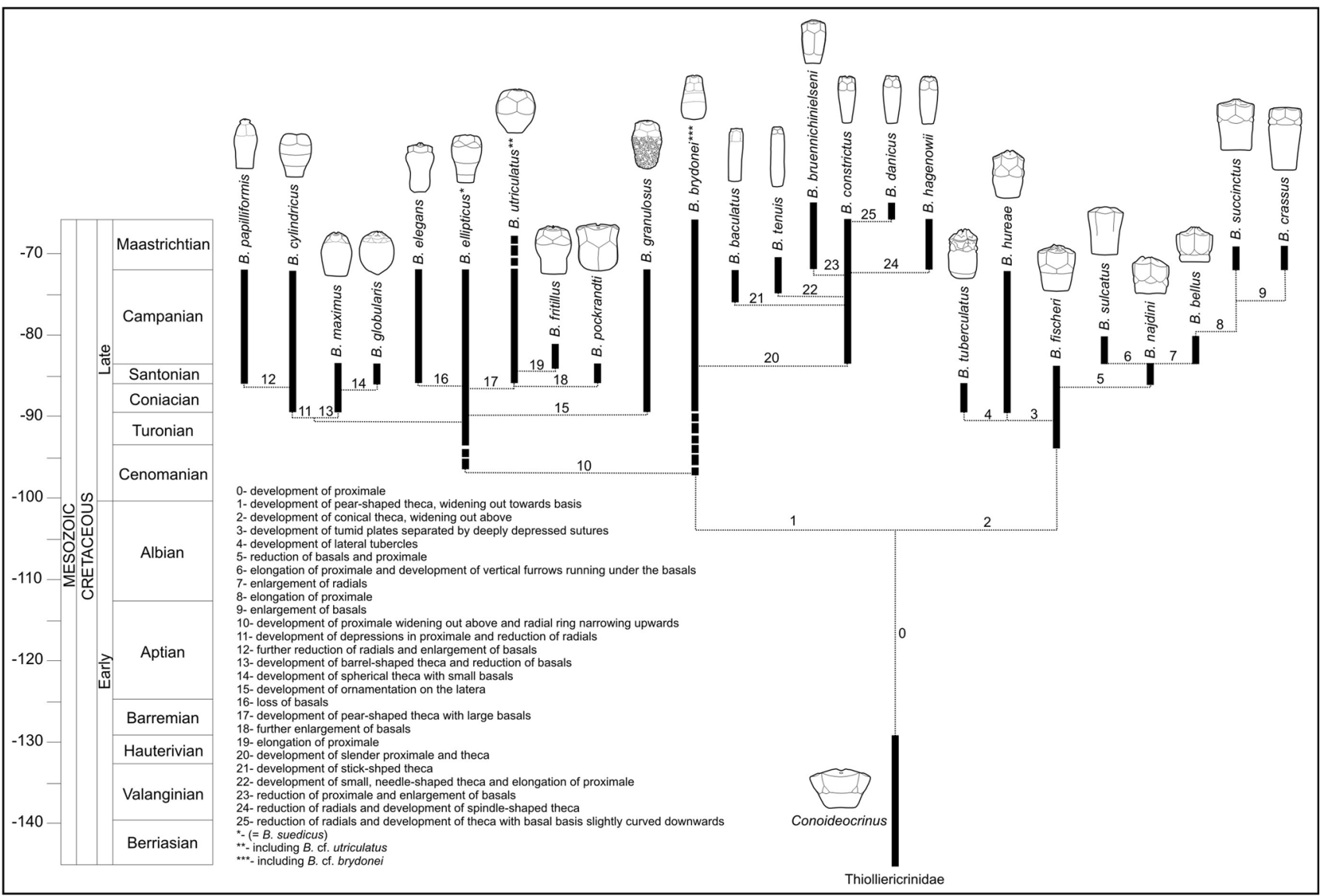

Fig. 10 Suggested phylogeny of Cretaceous bourgueticrinid crinoids

The second main evolutionary lineage that diverged in the Cenomanian/Turonian is represented by species displaying conical theca widening out above. B. fischeri is the oldest species of this lineage. This form possesses low proximale, low and slightly convex basals, and fairly large radials. This form appears to be ancestral to $B$. hureae and $B$. tuberculatus, which displays tumid plates separated by deeply depressed sutures (Fig. 10). In the line leading to $B$. crassus, which also likely descends from $B$. fischeri, significant reversions can be observed. For example, there is a trend to build theca with reduced basals and proximale in the older species (B. najdini and B. bellus), but this trend is reversed in the younger species (B. succinctus and $B$. crassus) (Fig. 10).

Acknowledgments The author is greatly indebted to Bruno Ferré (Sotteville-lès-Rouen, France) and an anonymous reviewer for their constructive comments and suggestions. This project was supported by NCN grant DEC-2012/07/N/ST10/04103. Thanks are due to Ulrich Kotthoff (Universität Hamburg), Christian Neumann (Museum für Naturkunde in Berlin), and Tim Ewin (Natural History Museum in London) for the loan of German and English crinoid material in their care. Thanks are also due to Michał Zatoń (University of Silesia) for his help in assigning epibionts.
Open Access This article is distributed under the terms of the Creative Commons Attribution 4.0 International License (http://crea tivecommons.org/licenses/by/4.0/), which permits unrestricted use, distribution, and reproduction in any medium, provided you give appropriate credit to the original author(s) and the source, provide a link to the Creative Commons license, and indicate if changes were made.

\section{References}

Abel, O. 1927. Lebensbilder aus der Tierwelt der Vorzeit. Jena: G. Fischer.

Agassiz, L. 1836. Prodrome d'une Monographie des Radiaires ou Echinodermes. Mémoires de la Société des Sciences naturelles de Neuchâtel 1: 168-199.

Bather, F.A. 1889. Note on Marsupites testudinarius, v. Schlotheim sp. Quarterly Journal of the Geological Society of London 45: 172-174.

Baumiller, T.K., and C.G. Messing. 2007. Stalked crinoid locomotion, and its ecological and evolutionary implications. Palaeontologia Electronica 10(1): 1-10.

Baumiller, T.K., M.A. Salamon, P. Gorzelak, R. Mooi, ChG Messing, and F.J. Gahn. 2010. Post-Paleozoic crinoid radiation in response to benthic predation preceded the Mesozoic marine revolution. Proceedings of the National Academy of Sciences of the United States of America 107(13): 5893-5896. 
Besairie, H. 1936. Recherches géologiques à Madagascar. La géologie du Nord-Ouest. Mémoires de l'Académie Malgache 21: 1-259.

Boll, E. 1846. Geognosie der deutschen Ostseeländer zwischen Eider und Oder. Neubrandenburg: C. Brünslow.

Breimer, A., and N.G. Lane. 1978. Paleoecology. In Treatise on invertebrate paleontology, pt. T1, eds. R.C. Moore, and C. Teichert, 316-347. Lawrence: Geological Society of America and University of Kansas.

Brydone, R.M. 1912. The Stratigraphy of the Chalk of Hants. London.

Brydone, R.M. 1938. On correlations of some of the Norfolk exposures of chalk with Belemnitella mucronata. London: Dulau and Co.

Carpenter, P.H. 1881. On two new crinoids from the upper chalk of Southern Sweden. Quarterly Journal of the Geological Society of London 37: 128-136.

Clark, A.H. 1908. New genera of unstalked crinoids. Proceedings of the Biological Society 21: 125-136. (Washington).

Dames, W. 1885. Petrefacten aus dem Daghestán und der Turkmenensteppe. Zeitschrift der Deutschen Geologischen Gesellschaft 37: $218-221$.

Dixon, F. 1850. The geology and fossils of the Tertiary and Cretaceous formation of Sussex, Longman, Brown. London: Green and Longmans.

Donovan, S.K., S.A. Miller, A.P. Graham, and H.L. Dixon. 1994. New fossil crinoids from Jamaica. Journal of Paleontology 68(4): 842-845.

Donovan, S.K., C.V. Milsom, and C.J. Veltkamp. 1996. Jamaican Cretaceous Crinoidea. Journal of Paleontology 70(4): 866-871.

d'Orbigny, A.D. 1840-1858. Histoire naturelle générale et particulière des Crinoïdes, vivans et fossiles, comprenant la description zoologique et géologique de ces animaux. (The author), Paris. [1840: 1-32, pls 1-6; 1840: 33-64, pls 7-12; 1841: 65-96, pls 13-18; 1858: 97-98].

d'Orbigny, A.D. 1850 Prodrôme du paléontologie stratigraphique universelle des animaux mollusques et rayonnés faisant suite au cours élémentaire de paléontologie et de géologie stratigraphiques. Masson, Paris. [1850: 1x + 394; 1850: 428; 1852: $196+190$ index].

Gislén, T. 1924. Echinoderm studies. Zoologiska Bidrag Uppsala 9: $1-330$.

Głuchowski, E. 1987. Jurassic and Early Cretaceous articulate Crinoidea from the Pieniny Klippen Belt and the Tatra Mts., Poland. Studia Geologica Polonica 94(8): 7-102.

Gorzelak, P., and M.A. Salamon. 2009. Signs of benthic predation on Late Jurassic stalked crinoids; preliminary data. Palaios 24: 70-73.

Gorzelak, P., and M.A. Salamon. 2013. Experimental tumbling of echinoderms-Taphonomic patterns and implications. Palaeogeography Palaeoclimatology Palaeocology 386: 569-574.

Gorzelak, P., M.A. Salamon, and T.K. Baumiller. 2012. Predator induced macroevolutionary trends in Mesozoic crinoids. Proceedings of the National Academy of Sciences of the United States of America 109(18): 7004-7007.

Hammer, Ø., D.A.T. Harper, and P.D. Ryan. 2001. PAST: palaeontological statistics software package for education and data analysis. Palaeontologia Electronica 4(1): 1-9.

Hammer, Ø., and D.A.T. Harper. 2006. Paleontological data analysis. Oxford: Blackwell.

Hess, H. 1999. Uintacrinus beds of the upper cretaceous niobrara formation, Kansas, USA. In Fossil crinoids, ed. H. Hess, W.I. Ausich, C.E. Brett, and M.J. Simms, 225-232. Cambridge: Cambridge University Press.

Hess, H., and C.G. Messing. 2011. Treatise on invertebrate paleontology, part $T$, echinodermata 2, crinoidea, vol. 3. Lawrence: The University of Kansas, Paleontological Institute.
Hyman, L.H. 1955. The invertebrates: echinodermata. The coelomate Bilateria, 4. New York: McGraw-Hill Book Co.

Jaekel, O. 1904. Ueber einen Pentacriniden der deutschen Kreide. Sitzungs-Berichte der Gesellschaft Naturforschender Freunde zu Berlin (9): 191-196

Jaekel, O. 1918. Phylogenie und System der Pelmatozoen. Paläontologische Zeitschrift 3(1): 1-128.

Jagt, J.W.M. 1995. Late Cretaceous and early Cainozoic crinoid assemblages from northeast Belgium and the southeast Netherlands. In Echinoderm Research 1995. 4th Proceedings of European Echinoderm Colloquium, eds. R. Emson, A.B. Smith, and A. Campbell, 185-196. London: A.A. Balkema, Rotterdam/Brookfield.

Jagt, J.W.M. 1999. Late Cretaceous-Early Palaeogene echinoderms and the K/T boundary in the southeast Netherlands and northeast Belgium-Part 2: crinoids. Scripta Geologica 116: 59-255.

Jagt, J.W.M., and M.A. Salamon. 2007. Late Cretaceous bourgueticrinid crinoids from southern Poland-Preliminary observations. Scripta Geologica 134: 61-76.

Kirk, E. 1911. The structure and relationships of certain eleutherozoic Pelmatozoa. Proceedings U. S. National Museum 41: 1-137.

Kjaer, C.R., and E. Thomsen. 1999. Heterochrony in bourgueticrinid sea-lilies at the Cretaceous/Tertiary boundary. Paleobiology 25(1): 29-40.

Klikushin, V.G. 1975. Austinocrinus of the Soviet Union. Paleontologicheskiy zhurnal (3): 94-100. (in Russian).

Klikushin, V.G. 1982. Cretaceous and Paleogene Bourgueticrinina (Echinodermata, Crinoidea) [sic] of the USSR. Geobios 15(6): 811-843.

Klikushin, V.G. 1983. Distribution of crinoidal remains in the Upper Cretaceous of The USSR. Cretaceous Research 4: 101-106.

Klikushin, V.G. 1985. New Late Cretaceous and Paleogene crinoids from the Caspian region. Paleontologichesky sbornik 22: 44-50.

Klikushin, V.G. 1987. Thiolliericrinid crinoids from the Lower Cretaceous of Crimea. Geobios 20(5): 625-665.

Klikushin, V.G. 1992. Fossil pentacrinid crinoids and their occurrence in the USSR. Sanct-Peterburg: Leningrad Paleontological Laboratory. (in Russian).

Lach, R. 2016. Late Cretaceous sea lilies (Crinoids; Crinoidea) from the Miechów Trough. Southern Poland. Palaeontographica Abteilung A. 305(4-6): 91-133.

Loriol, P. de. 1882-1889. Paléontologie francaise, ou description des fossiles de la France. Sér. 1, Animaux invertébrés. Terrain jurassique, 11. Crinoides. G. Masson, Paris. [1882-1889: $627+580$, pls 229].

Łukowiak, M., and P. Gorzelak. 2006. Marsupites (Crinoidea, Uintacrinida) as a stratigraphic marker of Upper Santonian strata in the glacial rafts of eastern Poland. Przeglad Geologiczny 54: 784-786.

M'Coy, F. 1848. On some new Mesozoic Radiata. Annals and Magazine of Natural History (series 2) 2: 397-420.

Miller, J.S. 1821. A natural history of the Crinoidea or lily-shaped animals, with observations on the genera Asteria, Euryale. Bryan, Bristol: Comatula and Marsupites.

Milsom, C.V., M.J. Simms, and A.S. Gale. 1994. Phylogeny and palaeobiology of Marsupites and Uintacrinus. Palaeontology 37(3): 595-607.

Niedźwiedzki, R., and M.A. Salamon. 2005. Late Cretaceous crinoids from the Sudetes (southern Poland). Freiberger Forschungshefte. Paläontologie Stratigraphie Fazies C507: 1-9.

Nielsen, K., and Brünnich. 1913. Crinoiderne i Danmarks Kridtaflejringer. Danmarks geologiske Undersøgelse (II. Rakke) 26: 1-120.

Oji, T., M. Kanoh, S. Toshimitsu, and M. Tashiro. 1996. Nielsenicrinus japonicus new species (Echinodermata: Crinoidea) from the Late Cretaceous of Japan and its paleobiogeographic implications. Journal of Paleontology 70(4): 964-968. 
Reich, M., and P. Frenzel. 2002. Die Fauna und Flora der Rügener Schreibkreide (Maastrichtium, Ostsee). Archiv für Geschiebekunde 3(2-4): 73-284.

Reich, M., L. Villier, and M. Kutscher. 2004. The Echinoderms of the Rügen White Chalk (Maast-richtian, Germany). In Echinoderms: München, ed. T. Heinzeller, and J. Nebelsick, 495-501. London: Taylor \& Francis Group.

Rasmussen, H.W. 1961. A monograph of the Cretaceous Crinoidea. Det Kongelige Danske Videnskabernes Selskab, Biologiske Skrifter 12: 1-428.

Remin, Z. 2004. Biostratigraphy of the Santonian in the SW margin of the Holy Cross Mountains near Lipnik, a potential reference for extra-Carpathian Poland. Acta Geologica Polonica 54: 587-596.

Remin, Z. 2010. Upper Coniacian, Santonian, and lowermost Campanian ammonites of the Lipnik-Kije section, central Poland-Taxonomy, stratigraphy, and palaeogeographic significance. Cretaceous Research 31: 154-180.

Roemer, F.A. 1840-1841. Die Versteinerungen des norddeutschen Kreidegebirges. Hannover: Hahn. [iv + 1-48, pls 1-7 (1840); 49-145, pls 8-16 (1841)].

Roux, M., M. Eléaume, L.G. Hemery, and N. Améziane. 2013. When morphology meets molecular data in crinoid phylogeny: A challenge. Cahiers de Biologie Marine 54: 541-548.

Salamon, M.A. 2007. First record of bourgueticrinid crinoids from the Cenomanian of southern Poland. Cretaceous Research 28: 495-499.

Salamon, M.A. 2009. Early Cretaceous (Valanginian) sea lilies (Echinodermata, Crinoidea) from Poland. Swiss Journal of Geosciences 102(1): 77-88.

Salamon, M.A., A. Gajerski, P. Gorzelak, and M. Łukowiak. 2007. A new plicatocrinid [tetracrinid?] crinoid, Tetracrinus jagti, from the Cenomanian (Upper Cretaceous) of southern Poland. Neues Jahrbuch für Geologie und Paläontologie Abhandlungen 245(2): 179-183.

Salamon, M.A., P. Gorzelak, A. Gajerski, J. Kaźmierczak, and T. Borszcz. 2009. A concentration crinoid lagerstätte in the Turonian (Late Cretaceous) Conulus Bed (Miechów-Wolbrom area, Poland). Geobios 42(3): 351-357.

Salamon, M.A., and P. Gorzelak. 2010. Late Cretaceous crinoids (Crinoidea) from Eastern Poland. Palaeontographica Abt A 291: $1-43$.

Salamon, M.A., and P. Gorzelak. 2011. Late Cretaceous (SantonianCampanian) sea lilies (Echinodermata, Crinoidea) from the glacial rafts of North-Western Poland. Paläontologische Zeitschrift 85(2): 128-137.

Salamon, M.A., P. Gorzelak, R. Niedźwiedzki, D. Trzęsiok, and T.K. Baumiller. 2014. Trends in shell fragmentation as evidence of mid-Paleozoic changes in marine predation. Paleobiology 40(1): 14-23.

Schlüter, C. 1878. Über einige astylide Crinoiden. Zeitschrift der Deutschen Geologischen Gesellschaft 3: 28-66.
Seilacher, A., and R.B. Hauff. 2004. Contructional morphology of pelagic crinoids. Palaios 19: 3-16.

Sieverts, H. 1927. Über die Crinoidengattung Marsupites. Abhandlungen der Preußischen Geologischen Landesanstalt 108: 1-73.

Sieverts-Doreck, H. 1952. Articulata. In Classe de Crinoïdes. Traité de Paléontologie, 3, ed. G. Ubaghs, 658-773. Paris: Masson \& Cie.

Smith, A.B., and C.W. Wright. 2002. Echinoderms. In Fossils of the Chalk, 2nd ed, ed. A.B. Smith, and D.J. Batten, 251-295. London: The Palaeontological Association.

Springer, F. 1901. Uintacrinus: its structure and relations. Memoirs of the Museum of Comparative Zoölogy at Harvard College 25(1): $1-89$.

Springer, F. 1911. Some new American fossils crinoids. Memoirs of the Museum of Comparative Zoölogy at Harvard College 25: $117-161$

Stolley, E. 1892. Die Kreide Schleswig-Holsteins. Mitteilungen aus dem Mineralogischen Institut der Universität Kiel 1: 191-309.

Struve, W. 1957. Ein Massengrab kreidezeitlicher Seelilien. Die Uintacrinus-Platte des Senkenberg-Museums. Natur und Volk 87: 361-373.

Valette, A. 1917. Note sur les crinoïdes de la Craie blanche. Bulletin de la Société des Sciences historiques et naturelles de l'YonneScience Society of Natural History, Yonne [1916](2me Semestre): 79-178.

von Schlotheim, E.F. 1820. Die Petrefactenkunde auf ihrem jetzigen Standpunkte durch die Beschreibung seiner Sammlung versteinerter und fossiler Überreste des Thier- und Pflanzenreichs der Vorwelt erläutert. Gotha: Beckersche Buchhandlung.

von Hagenow, F. 1840. Monographie der Rügen'schen Kreideversteinerungen. II. Abteilung: Radiarien und Annulaten. Nebst Nachträgen zur ersten Abtheilung. Neues Jahrbuch für Mineralogie, Geognosie, Geologie und Petrefaktenkunde 1840: 631-672.

von Meyer, H. 1836. Mittheilungen, an Professor Bronn gerichtet. Neues Jahrbuch für Mineralogie, Geognosie, Geologie und Petrefaktenkunde 1836: 55-61.

Walaszczyk, I. 1992. Turonian through Santonian deposits of the Central Polish Uplands; their facies development, inoceramid paleontology and stratigraphy. Acta Geologica Polonica 42: $1-122$.

Whittlesea, P.S. 1991. The Maastrichtian in Norfolk. Bulletin of the Geological Society of Norfolk 40: 33-51.

Wright, C.W., and A.B. Smith. 1987. Echinoderms. In Fossils of the Chalk. Palaeontological Association, Field Guides to Fossils, 2, eds. E. Owen and A.B. Smith, 201-237. London.

Zittel, K.A. 1879. Handbuch der Palaeontologie. Bd. 1. Palaeozoologie. Abt. 1. Oldenbourg, München und Leipzig. [1879: viii +765$]$. 